Salimulloh Tegar Sanubarianto - Implikatur Ungkapan Bahasa Daerah dalam Gugatan Penghinaan dan Pencemaran Nama Baik di NTT: Sebuah Studi Kasus Linguistik Forensik

\title{
IMPLIKATUR UNGKAPAN BAHASA DAERAH DALAM GUGATAN PENGHINAAN DAN PENCEMARAN NAMA BAIK DI NTT: SEBUAH STUDI KASUS LINGUISTIK FORENSIK
}

\author{
Salimulloh Tegar Sanubarianto \\ Kantor Bahasa Provinsi NTT, Kupang, Indonesia \\ Email: salimulloh@gmail.com
}

Article history:

Submitted Oct 11, 2020

Revised Nov 04. 2020

Accepted March 09, 2021

Published June 13, 2021

\begin{abstract}
Trends in lawsuits against violations of UU ITE relate to insults and defamation have increased significantly in the past three years, not least in NTT. Some of the cases in the lawsuit included regional expressions. One of them is the case of UU ITE with the decision number 84/Pid.Sus/2019/PN Olm. With the method of indepth and documentative interviews, this study aims to reveal the implicature in the subject matter text through the Frank Parker implicature disclosure approach. The result showed that the motivation of speaker using local language expressions can be revealed through direct, indirect, and literal speech acts. In literal speech act, speech and implications have not negation. In direct speech act, speakers have implications to advise speech partners. Whereas indirect speech acts, speakers have implications to threaten the speech partners. The conclusion of this study indicate that local languages are effectively used to touch the personal identity of the speech partner so that they are often used to insult and defame.
\end{abstract}

Keywords: defamation; forensic linguistics; implicature; lawsuits; insults; UU ITE

\begin{abstract}
ABSTRAK
Tren gugatan pelanggaran UU ITE terkait penghinaan dan pencemaran nama baik meningkat secara signifikan dalam kurun waktu tiga tahun terakhir ini, tidak terkecuali di Nusa Tenggara Timur. Pokok perkara dalam gugatan tersebut beberapa di antaranya mencantumkan berbahasa daerah. Salah satunya perkara UU ITE dengan nomor putusan. 84/Pid.Sus/2019/PN Olm. Dengan metode wawancara mendalam dan dokumentatif, penelitian ini bertujuan mengungkap implikatur dalam teks pokok perkara tersebut lewat pendekatan pengungkapan implikatur Frank Parker. Hasil penelitian menunjukkan bahwa motivasi penutur menggunakan ungkapan bahasa daerah dapat diungkap lewat tindak tutur langsung, tak langsung, dan literal. Secara literal, tuturan dan implikasi tidak saling bernegasi. Secara tindak tutur langsung, penutur berimplikasi menasihati mitra tutur. Sedangkan secara tindak tutur tak langsung,
\end{abstract}


Salimulloh Tegar Sanubarianto - Implikatur Ungkapan Bahasa Daerah dalam Gugatan Penghinaan dan Pencemaran Nama Baik di NTT: Sebuah Studi Kasus Linguistik Forensik

penutur berimplikasi mengancam mitra tutur. Simpulan penelitian ini menunjukkan bahwa ungkapan bahasa daerah efektif digunakan untuk menyentuh identitas pribadi mitra tutur sehingga kerap digunakan untuk menghina dan mencemarkan nama baik.

Kata kunci: pencemaran; linguistik forensic; implikatur; gugatan; penghinaan; UU ITE

\section{PENDAHULUAN}

Tren gugatan penghinaan dan pencemaran nama baik terus mengalami peningkatan. Utamanya pascapembaruan UU ITE di tahun 2016. Tren tersebut juga terjadi di Provinsi Nusa Tenggara Timur, provinsi dengan penetrasi penggunaan internet hanya 55\% (Jatmiko, 2019). Hal ini juga tercermin dari inventarisasi permintaan penanganan kasus kebahasaan di Kantor Bahasa Nusa Tenggara Timur.

Faktanya, setelah diundang-undangkan sejak tahun 2008, pelaporan tentang pelanggaran pasal ini angkanya semakin meningkat. Perangkat perundang-undangan ini awalnya disusun untuk melindungi masyarakat dalam mengakses informasi dan bertransaksi elektronik. Undang-undang ini sempat diperbaru dengan Undang-Undang Nomor 19 Tahun 2016 tentang Perubahan atas Undang-Undang Nomor 11 Tahun 2008 tentang Informasi dan Transaksi Elektronik. Namun, justru yang kerap digunakan dalam ranah hukum adalah Pasal 27 Ayat 3 yang memuat tentang penghinaan dan pencemaran nama baik dengan media gawai elektronik. Hal ini bisa mengindikasikan dua hal: (1) pengetahuan hukum masyarakat semakin membaik dan (2) penggunaan bahasa di media sosial yang semakin tak terkendali (Sidik, 2013).

Kasus pidana penghinaan dan pencemaran nama baik di Nusa Tenggara Timur (baik KUHP maupun UU ITE) memiliki keunikan tersendiri. Hal ini disebabkan NTT memiliki 69 bahasa daerah yang aktif pula digunakan dalam bermedia sosial oleh masyarakat. Jadi, teks yang menjadi objek perkara pada kasus pidana penghinaan dan pencemaran nama baik bisa berasal dari 72 (Bahasa, 2020) bahasa daerah tersebut. 
Salimulloh Tegar Sanubarianto - Implikatur Ungkapan Bahasa Daerah dalam Gugatan Penghinaan dan Pencemaran Nama Baik di NTT: Sebuah Studi Kasus Linguistik Forensik

Beberapa bahasa daerah tersebut juga memiliki keunikan secara sosiokultural. Ada satu istilah atau idiom yang jika dialihbahasakan ke dalam bahasa Indonesia memiliki arti yang berkonotasi negatif, namun tidak pada bahasa tertentu, begitu pula sebaiknya. Ambil contoh saja bahasa Melayu Kupang yang disandingkan dengan bahasa Indonesia. Bahasa Melayu Kupang memiliki istilah bajingan. Dalam bahasa Melayu Kupang bajingan berarti 'gagah, keren, mengagumkan' (Jacob \& Grimes, 2003), sedangkan dalam bahasa Indonesia kosakata bajingan memiliki makna 'penjahat; pencopet; kurang ajar'. Dua makna yang bertolak belakang ini tentu akan menjadi sebuah pembeda dalam kasus tindak pidana penghinaan dan pencemaran nama baik.

Di sisi lain, ada sebuah idiom dalam bahasa Dawan yang jika dialihbahasakan dalam bahasa Indonesia bermakna pohonnya pencuri. Jika diamati secara semantik, idiom pohonnya pencuri tidak bermakna negatif dalam bahasa Indonesia. Namun, masyarakat Dawan menganggap idiom ini adalah makian superlatif. Pohonnya pencuri dapat diartikan 'asal-muasalnya pencuri atau pencuri di atas pencuri' (Edwards \& Bani, 2016). Perbedaan inilah yang membuat masalah kebahasaan dalam tindak pidana penghinaan dan pencemaran nama baik pada lokus Nusa Tenggara Timur semakin pelik.

Lebih lanjut, jika fokus pada Pasal 27 Ayat 3 UU ITE, tahun 2008 Indonesia dihebohkan dengan kasus Prita Mulyasari dengan RS OMNI Internasional. Prita yang semula berniat melayangkan kritik terhadap rumah sakit yang telah merawatnya tersebut dianggap menghina dan mencemarkan nama baik (MA, 2011). Berlanjut ke tahun 2017, saat komedian Muhadkly Acho diperkarakan oleh pengelola apartemen Green Pramuka atas sangkaan melanggar Pasal 27 Ayat 3 UU ITE. Muhadkly bersikukuh bahwa yang dia lakukan dengan beberapa penghuni apartemen tersebut adalah salah satu bentuk kritik, bukan penghinaan (Irawan, 2017). Dari dua kasus yang menjadi sorotan masyarakat tersebut, benang merah yang dapat ditarik adalah begitu tipisnya perbedaan antara mengkritik dan menghina. Teks atau tuturan yang semula diniatkan sebagai kritikan bisa direspons berbeda oleh penerima kritik. 
Salimulloh Tegar Sanubarianto - Implikatur Ungkapan Bahasa Daerah dalam Gugatan Penghinaan dan Pencemaran Nama Baik di NTT: Sebuah Studi Kasus Linguistik Forensik

Masalah seperti ini dalam lingkup yang lebih kecil juga terjadi di Nusa Tenggara Timur. Beberapa kasus pidana dengan landasan perkara Pasal 27 Ayat 3 UU ITE menyengketakan teks atau tuturan yang semula diniatkan untuk mengkritik kinerja pemerintah atau sebuah institusi. Namun, penerima kritik menganggapnya sebagai pencemaran nama baik.

Salah satu kasus yang menarik tentang penggunaan bahasa daerah pada gugatan penghinaan dan pencemaran nama baik adalah kasus dengan nomor putusan 84/Pid.Sus/2019/PN Olm. Kasus ini sudah berstatus hukum tetap. Penelitian ini bertujuan untuk mengungkapkan implikatur yang terkandung dalam teks pokok perkara berbahasa daerah. Penelitian ini tidak akan melakukan telaah ulang terhadap putusan atau pendekatan ahli bahasa yang ada dalam perkara tersebut.

Perkara dengan nomor putusan 84/Pid.Sus/2019/PN Olm mencantumkan teks-teks bahasa daerah dalam pokok perkaranya. Penelitian ini akan berupaya mengungkap implikatur dalam penggunaan bahasa daerah tersebut. Hal ini karena penutur cenderung lebih leluasa berekspresi menggunakan bahasa ibu. Bahasa ibu juga kerap dipilih untuk mengungkapkan makna-makna yang tidak bisa diungkapkan dalam lingua franca (McMenamin, 2002).

Berangkat dari pendahuluan di awal, penelitian ini akan mengungkap implikatur yang tersirat dalam sebuah teks pokok perkara penghinaan dan pencemaran nama baik dengan pendekatan teori Parker (Parker, 1986). Dengan menggunakan pendekatan tersebut, peneliti harapkan penelitian ini mampu mendeskripsikan sisi lain dari sebuah peristiwa tutur yang menyebabkan penghinaan dan pencemaran nama baik.

\section{TEORI DAN METODE PENELITIAN}

Penelitian ini masuk dalam lingkup linguistik forensik. Menurut Mc Menamin (McMenamin, 2002) linguistik forensik adalah studi ilmiah tentang bahasa yang diterapkan dengan tujuan forensik dan konteks. Linguistik 
Salimulloh Tegar Sanubarianto - Implikatur Ungkapan Bahasa Daerah dalam Gugatan Penghinaan dan Pencemaran Nama Baik di NTT: Sebuah Studi Kasus Linguistik Forensik

forensik adalah era baru dari linguistik. Sejak 2400 tahun ilmu linguistik, ilmu ini yang paling modern dan berkembang pesat. Menurut Coulthard dan Johnson (Coulthard \& Johnson, 2007), linguistik forensik menerapkan teoriteori linguistik secara terintegrasi dalam suatu peristiwa kebahasaan di ranah hukum, baik dalam bentuk produk hukum, interaksi dalam proses peradilan, dan dalam interaksi antarperorangan yang mengakibatkan timbulnya dampak hukum tertentu. Teori linguistik yang dimaksud adalah tata bahasa, tindak tutur, analisis wacana, linguistik kognitif, fonetik, fonologi, leksis, sintaksis, semantik, pragmatik, dan analisis wacana.

Lebih lanjut, menurut Coulthard dan Johnson(Coulthard \& Johnson, 2007), perhatian utama dari linguistik forensik adalah (1) bahasa dari dokumen legal, (2) bahasa dari polisi dan penegak hukum, (3) wawancara dengan subjek yang rentan dalam sistem hukum, (4) interaksi dalam ruang sidang, (5) buktibukti linguistik dan kesaksian ahli dalam persidangan, (6) kepengarangan dan plagiarism, (7) fonetik forensic dan identifikasi penutur. Dari objek perkara yang dijadikan fokus, penelitian ini menggabungkan bahasa dari dokumen legal dan wawancara dengan subjek yang rentan.

Bahasa memiliki peranan yang sangat besar dalam proses penegakan hukum. Bahasa merupakan alat yang praktis dan efektif dalam mengungkapkan kebenaran. Salah satu bidang bahasa yang mengkaji masalah hukum yaitu linguistik forensik. Linguistik forensik mengaplikasikan teoriteori lingustik dalam suatu peristiwa kebahasaan yang melibatkan proses hukum. Oleh karena itu, linguistik forensik merupakan kajian kebahahasan yang berkaitan dengan penyelidikan terhadap pelanggaran hukum.Harapannya penelitian ini, bisa menjadi salah satu sumbangan pemikiran untuk perkembangan linguistik forensik (Hasin et al., 2020).

Penelitian ini akan menggunakan implikatur sebagai pendekatan utama. Konsep implikatur pertama kali diperkenalkan oleh Herbert Paul Grice (1975) untuk memecahkan masalah mengenai makna bahasa yang tidak mampu diselesaikan oleh teori semantik biasa. Menurut Levinson (Levinson, 1983), 
Salimulloh Tegar Sanubarianto - Implikatur Ungkapan Bahasa Daerah dalam Gugatan Penghinaan dan Pencemaran Nama Baik di NTT: Sebuah Studi Kasus Linguistik Forensik

implikatur adalah kajian paling mengagumkan dalam pragmatik. Pengungkapan implikatur tidak bisa hanya menggunakan fitur-fitur semantis, perlu sebuah pengetahuan bersama dalam mengungkap implikatur secara utuh (Olshtain \& Cohen, 1990). Dalam lingkup linguistik forensik, implikatur memiliki fungsi khusus, yaitu untuk memperhitungkan apa yang diartikan atau apa yang dimaksudkan oleh penutur secara berbeda dari apa yang dinyatakan secara harfiah lewat tuturan (Lindayana et al., 2018).

Sebagai kajian berbasis teori implikasi, penelitian ini mengambil inspirasi dari tulisan I Dewa Putu Wijana, yaitu Implikatur dalam Wacana Pojok (Wijana, 2001). Wijana dalam tulisannya secara lugas mengungkapkan tindak tutur langsung, tak langsung, literal, dan tak literal dalam sebuah komentar redaksi yang menggelitik dari harian Kedaulatan Rakyat. Dengan berlandas teori Parker (Parker, 1986) Wijana mengungkap bahwa teks yang tertulis bisa mengandung makna tersembunyi, bahkan bernegasian. Meski begitu, kajian implikatur Wijana bukanlah, kajian linguistik forensik. Berbeda ranah dengan kajian ini, meski menggunakan teori telaah yang sama. Perspektif kebaruan yang ditawarkan oleh penelitian ini ada pada hal itu, yaitu memadukan teori implikasi untuk kajian linguistik forensik. Implikasi yang kerap digunakan untuk mengkaji analisis wacana kritis atau pragmatik kali ini digunakan untuk membedah linguistik forensik.

Implikatur sebetulnya bukan secara eksklusif milik kajian linguistik forensik. Implikatur bahkan bisa digunakan untuk menganalisis sebuah karya sastra seperti yang dilakukan oleh Risalatul Umami lewat penelitian berjudul Implikatur Percakapan Djaka Lodhang Edisi Januari-Juni Tahun 2013 (Umami, 2013). Dalam penelitian ini, implikatur digunakan sebagai pisau bedah untuk menganalisis sebuah percakapan yang ada pada karya sastra. Ternyata, karya sastra yang memproyeksikan karakter manusia dan mewujudkan percakapan-percakapannya mampu memunculkan implikatur pula. Karena implikatur memang produk sebuah dialog pragmatik yang tidak bisa dihindari. Penelitian ini tentu saja tidak mengambil karya sastra sebagai 
Salimulloh Tegar Sanubarianto - Implikatur Ungkapan Bahasa Daerah dalam Gugatan Penghinaan dan Pencemaran Nama Baik di NTT: Sebuah Studi Kasus Linguistik Forensik

objek penelitiannya. Implikasi dalam penelitian ini bukanlah produk rekaan, namun benar-benar fakta sosial yang ada pada masyarakat. Kebaruan penggunaan teori implikasi dalam penelitian ini juga ditunjukkan lewat perbedaan objek yang dianalisis antara karya sastra dan tuturan ranah linguistik forensik.

Lebih lanjut, penggunaan implikatur dalam wilayah kaji linguistik forensik bukanlah hal yang baru. Beberapa kajian telah menggunakan formula serupa. Misalnya, kajian Sri Waljinah yang berjudul Linguistik Forensik Interogasi: Kajian Implikatur Percakapan dari Perspektif Makna Simbolik Bahasa Hukum (Waljinah, 2016). Waljinah mengungkapkan implikaturimplikatur yang muncul saat proses interogasi dilakukan. Implikatur yang muncul dimaknai sebagai sebuah simbol dengan makna tersirat di dalamnya. Penelitian Waljinah turut melandaskan linguistik forensik sebagai wilayah kaji. Perbedaan mendasar penelitian Waljinah dengan penelitian ini tentu ada pada objek penelitian. Jika Waljinah memilih peristiwa tutur dalam proses interogasi, penelitian ini fokus pada teks sebuah unggahan media sosial yang menjadi pokok perkara dalam gugatan penghinaan dan pencemaran nama baik.

Penelitian ini adalah salah satu penelitian deskriptif kualitatif. Metode pengumpulan data yang digunakan adalah wawancara mendalam (in depth interviewing) dan dokumentatif. Moleong (Lexy, 2014) menyatakan bahwa wawancara mendalam adalah percakapan yang dilakukan oleh kedua belah pihak dengan maksud tertentu. Kedua pihak yaitu pewawancara yang mengajukan pertanyaan dan yang diwawancarai yang memberikan jawaban atas pertanyaan tersebut. Dalam konteks penelitian ini, tentu pewawancara adalah peneliti dan yang diwawancarai adalah beberapa informan termasuk pelapor, terlapor, dan pemangku adat suku Bajawa. Sementara dokumentatif adalah upaya peneliti untuk menelusuri referensi berupa dokumen yang mampu menunjang pembahasan dalam rangka menemukan jawaban dari pertanyaan penelitian. 
Salimulloh Tegar Sanubarianto - Implikatur Ungkapan Bahasa Daerah dalam Gugatan Penghinaan dan Pencemaran Nama Baik di NTT: Sebuah Studi Kasus Linguistik Forensik

Data yang dianalisis dalam penelitian ini terdiri atas dua jenis, yaitu data primer dan data sekunder. Data primer berupa rekaman tuturan langsung hasil wawancara peneliti dengan informan. Peneliti mengambil beberapa informan untuk melakukan wawancara mendalam. Di antaranya adalah terdakwa pada kasus tersebut, pelapor, penyidik kepolisian, pemangku adat suku Bajawa, dan pemerhati budaya. Sedangkan data sekunder peneliti ambil secara dokumentatif lewat beberapa referensi tentang adat istiadat suku bajawa. Di antaranya adalah Ritual Reba dalam Dinamika Budaya Suku Bajawa Flores NTT (Hoban \& Abut, 2019) dalam rangka memetakan hubungan sosial budaya antar-anggota suku Bajawa beserta konsekuensi-konsekuensi yang menyertainya, Pendidikan Karakter dalam Kosmologi Masyarakat Suku Bajawa di Flores-Nusa Tenggara Timur (Ngebu, 2018) untuk mengetahui sikap dan karakter dasar yang ditanamkan oleh masyarakat Bajawa dalam Pendidikan di lingkungan keluarga, dan Fungsi Sosial dan Transedental Tradisi Lisan DeroSagi Suku Bajawa-Ngada, Flores, Nusa Tenggara Timur (Sunarti, 2016) untuk mengetahui praanggapan dan implikatur yang mungkin muncul dalam tradisi lisan di lingkup masyarakat Bajawa.

Pendekatan yang digunakan untuk menganalisis teks tuturan tersebut adalah teori implikatur Parker (Parker, 1986). Dalam teori kerangka pikir Parker, pengungkapan implikatur dapat dibedakan menjadi menjadi empat, yakni (1) tindak tutur langsung, (2) tindak tutur tidak langsung, (3) tindak tutur literal, dan (4) tindak tutur nonliteral. Tindak tutur (speech acts) merupakan salah satu komponen penggunaan bahasa. Penggunaan bahasa tidak sematamata berhubungan dengan ketaatan pada kaidah gramatikal (Apriastuti, 2018). Penggunaan bahasa juga bersangkut paut norma sosial dari suatu masyarakat yang sering disebut kesantunan berbahasa antar anggota masyarakat dalam suatu komunitas tutur berbahasa.

Tindak tutur merupakan sarana mengekspresikan pikiran dan perasaan. Bertindak tutur, seseorang tidak selalu mengatakan apa yang dimaksudkan. Pembicara sering kali bermaksud lebih banyak daripada yang ia katakan secara 
Salimulloh Tegar Sanubarianto - Implikatur Ungkapan Bahasa Daerah dalam Gugatan Penghinaan dan Pencemaran Nama Baik di NTT: Sebuah Studi Kasus Linguistik Forensik

aktual. Seseorang sering kali memiliki maksud berbeda dengan apa yang dikatakannya, bahkan sering bertentangan (Ekawati, 2018). Penggunan pronominal dan idiom bahasa daerah dalam teks pokok perkara dengan nomor putusan 84/Pid.Sus/2019/PN Olm mengandung implikatur yang dapat diungkap dengan tindak tutur langsung dan tindak tutur tidak langsung.

\section{HASIL DAN PEMBAHASAN}

\section{Gambaran Umum Pokok Perkara}

Penjelasan pada bab awal sudah mencantumkan bahwa pertumbuhan perkara pidana terkait penghinaan dan pencemaran nama baik di Nusa Tenggara Timur semakin meningkat dari tahun ke tahun. Hal itu bisa dilihat secara eksplisit lewat tabel berikut.

Tabel 1. Daftar Permintaan Ahli Bahasa 2014-2019

\begin{tabular}{cccccc}
\hline No & Tahun & $\begin{array}{c}\text { Pasal 310 } \\
\text { KUHP }\end{array}$ & $\begin{array}{c}\text { Pasal 311 } \\
\text { KUHP }\end{array}$ & $\begin{array}{c}\text { Pasal 27 Ayat 3 } \\
\text { UU ITE }\end{array}$ & Pasal Lainnya \\
\hline 1 & 2014 & 12 & 2 & 10 & 3 \\
2 & 2015 & 21 & 14 & 18 & 7 \\
3 & 2016 & 27 & 15 & 32 & 12 \\
4 & 2017 & 36 & 14 & 31 & 11 \\
5 & 2018 & 48 & 23 & 41 & 13 \\
6 & 2019 & 51 & 25 & 65 & 11 \\
\hline
\end{tabular}

Sumber: Inventarisasi Kantor Bahasa NTT

Lewat data tersebut, dapat diamati bahwa dari tahun ke tahun tren tindak pidana penghinaan dan pencemaran nama baik terus meningkat. Peningkatan juga dialami pada pelaporan tindak pidana pemfitnahan meskipun tidak terlalu signifikan. Dari sisi pasal sangkaan, yang paling banyak dilaporkan adalah Pasal 27 Ayat 3 UU ITE.

Perkara dengan nomor putusan 84/Pid.Sus/2019/PN Olm berawal dari laporan yang dimasukkan oleh pelapor pada tahun 2018. Proses penyelesaian perkara membutuhkan waktu satu tahun sampai keluar putusan di tahun 2019. Pada tahun 2016, pelapor meminjam sejumlah uang pada terlapor. Berselang dua tahun, karena tidak kunjung lunas, terlapor mengunggah foto diri pelapor dengan disertai teks tuturan tertulis ke Facebook sebagai berikut. 
Salimulloh Tegar Sanubarianto - Implikatur Ungkapan Bahasa Daerah dalam Gugatan Penghinaan dan Pencemaran Nama Baik di NTT: Sebuah Studi Kasus Linguistik Forensik

"Hai si wajah cantik karena kepintaranmu kau pandai bersilat d membohongi banyak orang Kau Sogo Mau Songo Kau Wale Lopo Lae? Memang benar - benar manusia licik yang tidak tau diri inikah mau jadi DPR? bagi yang tidak tau tentang kepribadian kau pasti orang pilih tapi bagi yang tahu tentang kepribadian kau orang tidak akan pilih Jangan Besar Pasak Dari Pada Tiangnya."

Perlu diketahui pula, latar belakang pelapor dan terlapor. Pelapor adalah salah satu pengurus partai yang hendak mencalonkan diri menjadi anggota DPRD, sementara itu terlapor adalah salah satu guru di Kabupaten Ngada. Pelapor dan terlapor masih memiliki hubungan keluarga. Terlapor adalah adik dari ibu pelapor. Mereka berasal dari suku Bajawa di Kabupaten Ngada. Suku ini menganut konsep matrilineal, yang artinya mengikuti garis keturunan yang ditarik dari pihak ibu. Artinya, pelapor dan terlapor memiliki hubungan yang sangat dekat secara keluarga dan kesukuan.

\section{Pengungkapan Implikatur Lewat Tindak Tutur Langsung}

Sebelumnya perlu disepakati bahwa unggahan teks di Facebook yang menjadi objek penelitian ini adalah sebuah peristiwa tutur hanya saja medianya menggunakan tikan lewat media sosial. Hal ini karena ragam bahasa yang digunakan adalah ragam cakap. Pun maksud dari teks di Facebook tersebut adalah komunikasi dua arah antara penutur dengan mitra tutur. Sebagai sebuah peristiwa tutur, tentunya kalimat-kalimat dalam teks tersebut mengandung makna. Pembahasan ini fokus pada satu ungkapan bahasa daerah dalam teks. Ungkapan tersebut ditengarai mengandung implikatur yang bisa terungkap lewat tindak tutur langsung maupun tak langsung.

Tindak tutur langsung adalah tindak tutur yang maksud pertuturannya diungkapkan dengan kalimat-kalimat yang sesuai dengan modusnya, misalnya kalimat berita untuk memberitakan, kalimat perintah untuk memerintah, dan kalimat tanya untuk bertanya (Yuliarti et al., 2015). Teks tuturan (1) yang diunggah ke media sosial Facebook ini mengandung implikatur yang pengungkapannya secara langsung. 
Salimulloh Tegar Sanubarianto - Implikatur Ungkapan Bahasa Daerah dalam Gugatan Penghinaan dan Pencemaran Nama Baik di NTT: Sebuah Studi Kasus Linguistik Forensik

(1) Kau Sogo Mau Songo Kau Wale Lopo Lae?

Kalimat tersebut adalah kalimat bahasa Bajawa. Arti harfiahnya adalah "kau meminjam dengan merendah, kau mengembalikan dengan lalai?". Kalimat tersebut secara langsung ditujukan penutur kepada mitra tutur dan difungsikan sebagai kalimat pertanyaan. Artinya, secara sengaja penutur ingin menanyakan tindakan mitra tutur yang meminjam uang dengan cara baik-baik, namun tak kunjung berniat mengembalikan uang itu. Pengungkapan implikatur lewat tindak tutur langsung ini bisa ditelusuri dengan teknik dokumentatif tanpa memperdalam lagi lewat wawancara. Jika analisis teks tersebut hanya sampai di sini, tentu fakta yang diperoleh hanya sekadar sebuah kalimat pertanyaan dari penutur kepada mitra tuturnya. Padahal, jika ditelusuri lebih mendalam, ada implikatur lain yang mungkin muncul lewat penyimpangan fungsi kalimat.

\section{Pengungkapan Implikatur Lewat Tindak Tutur Tak Langsung}

Untuk memperoleh makna tersirat dari sebuah kalimat, ada banyak cara yang bisa digunakan. Karena peneliti bukanlah seorang penutur jati (native speaker) bahasa Bajawa, peneliti memutuskan melakukan wawancara kepada penutur mengapa memilih menggunakan kalimat (1) tersebut di tengah teks yang menggunakan bahasa Indonesia ragam cakap. Lewat proses wawancara tersebut, terungkaplah implikatur dengan tindak tutur tidak langsung.

Tindak tutur tidak langsung adalah tindak tutur yang maksud dan situasi pertuturannya diutarakan dengan modus kalimat yang tidak berkesesuaian (Wijana, 2001). Misalnya, kalimat tanya yang difungsikan untuk memerintah atau memberitakan atau kalimat berita yang berfungsi untuk memerintah.

Kalimat (1) merupakan ungkapan atau adagium dalam bahasa Bajawa yang memang sering digunakan masyarakat Bajawa menagih utang orang lain entah itu dalam bentuk barang maupun uang. Penutur sengaja menyelipkan 
Salimulloh Tegar Sanubarianto - Implikatur Ungkapan Bahasa Daerah dalam Gugatan Penghinaan dan Pencemaran Nama Baik di NTT: Sebuah Studi Kasus Linguistik Forensik

ungkapan ini karena mitra tuturnya datang dari suku yang sama dan bahasa ibu yang sama. Dalam teks unggahannya, penutur membubuhkan tanda tanya pada akhir kalimat yang artinya secara semantic harusnya kalimat tersebut berfungsi sebagai kalimat tanya. Namun, dalam sistem pola komunikasi di kalangan masyarakat Bajawa, ungkapan (1) tidak mungkin diutarakan jika memang masalahnya tidak pelik.

Penutur cenderung memfungsikan kalimat tanya tersebut sebagai kalimat yang menunjukkan pernyataan tuntutan. Hal ini terungkap dalam petikan wawancara peneliti dengan penutur sebagai berikut.

“... beta sengaja omong begitu na karena beta pangkat bibi tho, Pak dengan Ibu xxx. Kami orang Bajawa, apalagi orang tua ini pasti kasih tahu ke yang lebih muda. Omongan itu maksudnya beta mengingatkan, Lu sebagai orang Bajawa jangan begitu. Kalau pinjam harus tanggung jawab...." (MGL/21-05-2019/02.35)

Penyimpangan fungsi kalimat tanya ini menunjukkan pengungkapan implikatur lewat tindak tutur langsung. Namun, uniknya, fakta berbeda peneliti temukan lewat petikan wawancara dengan informan lain. Petikan wawancaranya sebagai berikut.

"Ungkapan tersebut memang umum digunakan masyarakat Bajawa. Fungsinya lebih ke ancaman. Jadi kalau memang kamu tidak bisa melunasi hutangmu berarti hal ini harus diselesaikan secara adat atau kesukuan. Karena orang Bajawa harga dirinya tinggi dan pinjam utang lalu tidak mengembalikan berarti melanggar nilai-nilai di masyarakat Bajawa itu sendiri ...." (RT/22-052019/00.15)

Dari petikan tersebut, peneliti berhasil mengungkap motivasi lain yang kemungkinan berpotensi menjadi implikatur dalam teks tersebut. Penutur menggeser posisi partisipan (penutur dan mitra tutur) yang sebelumnya adalah hubungan kekeluargaan berubah menjadi hubungan kesukuan. Sebagai sesama anggota suku, ada konsekuensi-konsekuensi yang harus dipatuhi, salah satunya adalah etika dalam meminjam dan mengembalikan pinjaman. Penutur melakukan penyimpangan fungsi semantis pada tuturan (1). Penutur, karena tahu mitra tuturnya juga merupakan anggota suku Bajawa, mengancam mitra 
Salimulloh Tegar Sanubarianto - Implikatur Ungkapan Bahasa Daerah dalam Gugatan Penghinaan dan Pencemaran Nama Baik di NTT: Sebuah Studi Kasus Linguistik Forensik

tuturnya dengan mengeluarkan tuturan (1). Penutur mencoba mengingatkan konsekuensi sebagai anggota suku Bajawa terhadap mitra tutur dan disimpangkan lewat ungkapan yang diperformakan sebagai kalimat tanya.

Hal ini sejalan dengan pemilihan campur kode yang digunakan oleh penutur. Penutur hanya menggunakan bahasa daerah pada bagian ungkapan (1), selebihnya penutur menggunakan bahasa Melayu Bajawa yang juga bisa dipahami oleh orang di luar suku Bajawa. Penutur secara sengaja menginginkan teks tersebut bisa dimengerti oleh banyak orang, tidak terbatas masyarakat di Bajawa. Namun, di bagian ungkapan (1) tersebut, karena menggunakan ungkapan kesukuan berbahasa daerah yang khas, penutur menginginkan implikasi yang berbeda dengan bagian-bagian teks yang menggunakan bahasa Melayu Bajawa. Jika dikaitkan denga hasil wawancara, implikasi yang diinginkan adalah komunikasi dengan nuansa internal kesukuan entah itu dimaksudkan sebagai wujud menasehati atau bahakan mengancam.

Penutur dalam teks tersebut memfungsikan implikatur sesuai dengan yang diungkapkan Levinson (Levinson, 1983), yaitu implikatur mampu memberi penjelasan fungsional yang bermakna atas fakta-fakta kebahasaan yang tidak dapat terjelaskan.

\section{Pengungkapan Implikatur Lewat Tindak Tutur Literal}

Keliteral maupun ketidakliteralan sebuah tindak tutur dan implikaturnya, dapat diamati dari kesearahan implikasi dengan tuturan kalimat. Jika kalimat tersebut berlawanan dengan implikasinya, pengungkapan implikatur bisa digunakan lewat tindak tutur takliteral. Jika kalimat tersebut tidak berlawanan dengan implikasinya atau dengan kata lain tidak saling bernegasian, pengungkapan implikatur bisa digunakan lewat tindak tutur literal (Wijana, 2001).

Kalimat tuturan (1) memiliki implikasi yang tidak bernegasi dengan kalimatnya. Implikasi tuturan (1) literal dengan kalimatnya. Tuturan tersebut 
Salimulloh Tegar Sanubarianto - Implikatur Ungkapan Bahasa Daerah dalam Gugatan Penghinaan dan Pencemaran Nama Baik di NTT: Sebuah Studi Kasus Linguistik Forensik

mensyaratkan kau meminjam dengan merendah, kau mengembalikan dengan lalai. Hal ini sejalan dengan kalimat tuturannya secara gramatikal dan semantis. Karena pada kenyataannya, mitra tutur yang menunjukkan proyeksi yang serupa dengan ungkapan bahasa daerah tersebut.

\section{SIMPULAN}

Simpulan dari penelitian ini bahwa penggunaan ungkapan bahasa daerah dalam suatu peristiwa tutur pada ranah linguistik forensik memiliki motivasi yang berbeda-beda. Apabila suatu teks yang didominasi bahasa Indonesia kemudian terdapat campur kode bahasa daerah di dalamnya, teks bahasa daerah tersebut perlu mendapat perhatian.

Hal itu terungkap dalam studi kasus teks pokok perkara dengan nomor putusan 84/Pid.Sus/2019/PN Olm. Lewat pendekatan teori Parker, terungkap bahwa implikatur bahasa daerah yang digunakan oleh penutur dapat diungkap lewat tindak tutur langsung maupun tak langsung.

Pengungkapan implikatur lewat tindak tutur langsung mengungkapkan bahwa penutur menggunakan kalimat tanya berupa ungkapan bahasa daerah untuk menanyakan tindakan mitra tutur. Di sisi lain, jika ditelaah menggunakan pengungkapan implikatur lewat tindak tutur tak langsung, fakta yang tersirat bisa berbeda. Penutur melakukan penyimpangan fungsi kalimat tanya dengan memfungsikannya untuk mengungkapkan keluhan dan mengingatkan mitra tuturnya atas konsekuensi-konsekuensi yang mungkin bisa terjadi.

Kajian linguistik forensik terus mengalami perkembangan di Indonesia. Semakin banyak peneliti yang melakukan kajian linguistik forensik belakangan ini sebagai imbas maraknya pelanggaran UU ITE, utamanya yang terkait penghinaan dan pencemaran nama baik. Fenomena ini sebenarnya menjadi pedang bermata dua bagi masyarakat Indonesia. Di satu sisi, literasi hukum masyarakat semakin meningkat, kajian linguistik forensik pun bisa tambah subur. Di sisi lain, masyarakat menjadi semakin rentan melakukan pelanggaran 
Salimulloh Tegar Sanubarianto - Implikatur Ungkapan Bahasa Daerah dalam Gugatan Penghinaan dan Pencemaran Nama Baik di NTT: Sebuah Studi Kasus Linguistik Forensik

UU ITE Hal ini diakibatkan indikator atau tolok ukur seseorang telah dihina atau dicemarkan nama baiknya masih begitu relatif.

Peneliti menyarankan kajian-kajian serupa dalam ranah linguistik forensik semakin banyak dilakukan dan dipublikasikan. Selain berdampak bagus untuk iklim akademis, suburnya kajian linguistik forensik mampu menjadi alternatif pengambilan keputusan dalam proses hukum. Selain itu, kajian-kajian tersebut bisa menjadi suatu telaah yurisprudensi bagi penegak hukum.

\section{DAFTAR PUSTAKA}

Apriastuti, N. N. A. A. (2018). Bentuk, fungsi, dan jenis tindak tutur dalam komunikasi siswa di kelas IX Unggulan SMP PGRI 3 Denpasar. Jurnal Ilmiah Pendidikan Dan Pembelajaran, 1(1), 164-175.

Bahasa, B. P. dan P. (2020). Peta bahasa. Kemdikbud.Go.Id. https://petabahasa.kemdikbud.go.id

Coulthard, M., \& Johnson, A. (2007). An Introduction to forensic linguistics. In Routledge Taylor and Francis Group. Routledge Taylor and Francis Group. https://doi.org/10.1201/b11275-2

Edwards, O., \& Bani, H. (2016). Kamus bergambar bahasa Amarasi. Jakarta: AuSIL.

Ekawati, M. (2018). Kesantunan semu pada tindak tutur ekspresif marah dalam bahasa Indonesia. Adabiyyāt: Jurnal Bahasa Dan Sastra, 1(1), 1. https:/ / doi.org/10.14421/ajbs.2017.01101

Hasin, K. I., Amir, J., \& Juanda. (2020). Implikatur percakapan terhadap siswa pelanggar aturan sekolah (kajian linguistik forensik interogasi). Indonesia: Jurnal Pembelajaran Bahasa Dan Sastra Indonesia, 1(1), 1--7.

Hoban, N., \& Abut, E. Y. (2019). Ritual reba dalam dinamika budaya suku Bajawa, Flores, NTT. Prolitera: Jurnal Penelitian Pendidikan, Bahasa, Sastra, Dan Budaya, 2(2), 75--81.

Irawan, B. A. (2017). Pengaruh penggunaan twitter manajemen Green Pramuka City terhadap pemenuhan kebutuhan informasi bagi follower [Universitas Multimedia Nusantara]. In Universitas Multimedia Nusantara. https:// doi.org/10.1136/ip.2010.029629

Jacob, J., \& Grimes, C. E. (2003). Kamus Pengantar bahasa Melayu Kupang. Artha Wacana Press.

Jatmiko, L. D. (2019). Setengah penduduk di provinsi ini buta internet. Teknologi Bisnis. 
Salimulloh Tegar Sanubarianto - Implikatur Ungkapan Bahasa Daerah dalam Gugatan Penghinaan dan Pencemaran Nama Baik di NTT: Sebuah Studi Kasus Linguistik Forensik

https:/ / teknologi.bisnis.com/read/20190521/101/925206/ setengahpenduduk-di-provinsi-ini-buta-internet

Levinson, S. C. (1983). Pragmatics. Cambridge University Press.

Lexy, M. (2014). Metode penelitian kualitatif. PT Remaja Rosdakarya.

Lindayana, Arifuddin, \& Mandala, H. (2018). Divergent principles of politeness in verbal and non-verbal directive speech act. International Research Journal of Engineering, IT \& Scientific Research, 4(2), 41. https:// doi.org/10.21744/irjeis.v4i2.640

McMenamin, G. R. (2002). Forensic linguistics: advances in forensic stylistics. in CRC Press. CRC Press. https://doi.org/10.1002/9780470756409.ch30

Ngebu, J. F. (2018). Pendidikan karakter dalam kosmologi masyarakat suku Bajawa Di Flores-Nusa Tenggara Timur. Prosiding Seminar Nasional Geotik 2018, 62-69.

Olshtain, E., \& Cohen, A. (1990). The learning of complex speech act behaviour. TESL Canada Journal, 7(2), 45. https://doi.org/10.18806/tesl.v7i2.568

Parker, F. (1986). Linguistics for nonlinguists. Routledge and Kegan Paul.

Sidik, S. (2013). Dampak Undang-Undang Informasi dan Transaksi Elektronik (UU ITE) terhadap perubahan hukum dan sosial masyarakat. Jurnal Ilmiah Widya, 1(1), 7--20.

Sunarti, S. (2016). Fungsi sosial dan transendental tradisi lisan Dero-Sagi Suku Bajawa-Ngada, Flores, Nusa Tenggara Timur. JENTERA: Jurnal Kajian Sastra, 5(1), 86. https:/ / doi.org/10.26499/jentera.v5i1.350

Umami, R. (2013). Implikatur percakapan dalam wacana pojok pada Djaka Lodang Edisi Januari-Juni Tahun 2013. Jurnal Program Studi Pendidikan Bahasa Dan Satra Jawa_Universitas Muhammadiyah Purworejo, 03(02), 47-51.

Waljinah, S. (2016). Linguistik forensik interogasi: kajian implikatur percakapan dari perspektif makna simbolik bahasa hukum. International Seminar Prasasti III, 740-744.

Wijana, I. D. P. (2001). Implikatur dalam wacana pojok. Humaniora, 13(3), 340346. https:/ / doi.org/10.33369/pgsd.9.3.340-346

Yuliarti, Rustono, \& Nuryatin, A. (2015). Tindak tutur direktif dalam wacana novel Trilogi karya Agustinus Wibowo. Seloka: Jurnal Pendidikan Bahasa Dan Sastra Indonesia, 4(2), 78-85. 


\title{
THE COLLOCATION MEANING OF "VACCINE" ON SEMANTIC APPROACH: A CORPUS-BASED ANALYSIS
}

\author{
Wulansari \\ Universitas Airlangga, Surabaya, Indonesia \\ Email: wulansari-2019@fib.unair.ac.id
}

\begin{tabular}{c} 
Article history: \\
Submitted March 23, 2021 \\
Revised April 13, 2021 \\
Accepted May 17. 2021 \\
Published June 29, 2021 \\
\hline
\end{tabular}

\begin{abstract}
Corpus semantics examines the words that are used in text and discourse using observations as evidence of meaning. This study aims to investigate the collocations of node 'vaccine' based on semantic preference and semantic prosody using the corpus-based approach since the source of data is the corpus data. The qualitative research method is used to find the hypotheses from the corpus data taken from sub-corpus in Covid-19 corpus using Sketch Engine software. This study demonstrates that the node word of 'vaccine' in the semantic preference was shown six words related to the Covid-19 corpus. Meanwhile, the category of semantic prosody was displayed four words negative in meaning, and there was two words displayed positive in meaning, the collocations with negative meaning which occur more frequently than positive meaning. Thus, the writer concluded that the author of a reputable journal explained the word 'vaccine' with a negative perspective in Covid-19.
\end{abstract}

Keywords: collocation; covid-19; semantic preferences; semantic prosody

\begin{abstract}
ABSTRAK
Semantik Corpus mempelajari kata-kata yang digunakan dalam teks dan wacana menggunakan pengamatan sebagai makna bukti. Penelitian ini bertujuan untuk menyelidiki kolokasi node 'vaksin' berdasarkan preferensi semantik dan prosodi semantik menggunakan pendekatan berbasis corpus karena sumber data adalah data corpus. Metode penelitian kualitatif digunakan untuk menemukan hipotesis dari data corpus yang diambil dari sub-corpus dalam Covid-19 corpus menggunakan perangkat lunak Sketch Engine. Hasil penelitian ini menunjukkan bahwa simpul kata 'vaksin' dalam preferensi semantik ditampilkan enam kata yang terkait dengan Covid-19 corpus. Sementara itu, kategori prosodi semantik ditampilkan empat kata negatif dalam arti dan ada dua kata ditampilkan positif dalam arti, collocations dengan makna negatif yang terjadi lebih sering daripada makna positif. Dengan demikian, penulis menyimpulkan bahwa penulis
\end{abstract}

